\title{
Licensed to Traffic: The Sex Trade in Bangladesh
}

\author{
Seetharam Mukkavilli
}

\section{Abstract}

An overview of the conditions underlying the flourishing Bangladeshi trafficking trade. Cross-border sales of women and girls are common, and prostitution is said to function on a scale comparable to otherdomestic industry. However, gaining an accurate understanding of the magnitude of trafficking is made very difficult by a lack of proper documentation. Despite legal provisions prohibiting the flesh trade, the abuse of well-intentioned laws results in a successful eoasion of penalization by the many who benefit from the trafficking of women and girls.

\section{Précis}

Un aperçu des conditions sous-jacentes d la traite des blanches au Bangladesh, où le commerce inter-frontalier defemmes et de jeunes filles est courant et passe pour fonctionner sur uneéchelle comparabled cellede toute autre industrie domestique. Pourtant, l'acquisition d'une meilleure compréhension de l'ampleur et de la sophistication de la traite des blanches est rendue fort difficile par un manque chronique de documentation adéquate. Malgré les dispositions légales prohibant le commerce de la chair, les lacunes de ces lois bien intentionnés permettent toujours aux nombreux profiteurs dece trafic des femmes et des jeunes filles de se préserver une fructueuse impunité juridique.

Bangladesh was born in 1991, following a liberation war. Previously, it had been known as East Bengal, and formed

Seetharam Mukkavilli, Ph.D., associated with Prasna Intermational Consulting, has been a technical advisor to multilateral agencies, including UNICEF and UNDP. He is currently working on behalf of the Foundation for Intemational Training on a development project which seeks to strengthen the capacities of organizations in the Bangladeshi NGO sector. part of Pakistan. Women constitute nearly half of the total population, which is estimated at 120 million. Trafficking in women is not a new problem in Bangladesh.

\section{The Etiology}

In Bangladesh, the root causes of trafficking in women are primarily economic and social. Pervasive poverty and unemployment leads women and underaged girls to engage in flesh trade for survival. The extensive network of trafficking agents facilitates the luring of gullible women and girls to big cities with promises of good jobs. Most often, the profession is taken up involuntarily. Underaged girls are beaten and raped by men, in order to break down their social defences. This is a clear violation of human rights.

In addition, the following social factors are among those which influence women: discrimination, a subordinate social position, large families lacking basicfood, inhumane treatment by stepmothers, divorce, social ostracization, the urban "pull."

\section{The Magnitude}

There are two categories of prostitutes: "stationary" prostitutes, operating from brothels; and "floating" prostitutes, or call girls, who are mobile. Floating prostitutes roam in the commercial and residential areas of major urban centres, while the shop keepers acting as pimps retain much of the prostitutes' earnings. Some of the girls' parents receive a daily allowance from the pimps.

According to one government figure, there are 9,017 prostitutes in Bangladesh, 3,578 of whom are considered floating prostitutes. However, unofficial reports place the total number of prostitutes at more than 100,000 , and half of them are teenagers (Maudud 1992, 80-81). As quoted in a publication issued by thenon-governmental organization Bangladesh Mahila Parishad, a
1998 report by the Coalition Against the Trafficking of Women states that 500 Bangladeshi women are illegally transported into Pakistan every day, indicating the staggering number of women who are trafficked daily across national borders.

\section{A Profile of Sex-Workers}

According to the aforementioned publication, a study of 32 girls rescued from brothelshelps toillustrate the socio-economic factors affecting the lives of women in Bangladesh. The girls, aged 10 to 16 years, left home after experiencing oppression at the hands of their own families, facing such difficulties as orphanhood, abandonment, remarriage of their natural fathers and the ensuing torture inflicted by stepmothers. Many left their abodes in the hope of finding jobs as housemaids and a better life in Dhaka, the country's capital.

For the most part, the girls were illiterate and came from the poorer strata of society. They were enticed into the flesh trade by rickshaw pullers, elderly domestic servants, and other women. The brothel-keepers, older women known as "sardarnis," tortured the girls for money and punished them if they tried to escape from the brothels.

\section{Legal Provisions}

In Article No. 18(2) of the Constitution of the People's Republic of Bangladesh, it is written that the state shall adopt effective measures to prevent prostitution and gambling. The Penal Code (Act. XLV of 1860) deals with the issue of trafficking in women. Article 366 demands severe punishment of those forcing women into the sex trade. Article 366A and Article 372 prohibit the prostitution of women below the age of 18 years. However, as in many situations, loopholes in well-meaning laws are being abused by those in the flesh trade wishing to protect their own interests. 
The practice of prostitution is legal if one can obtain an affidavit. In accordance with the law, anyone aged 18 and above can volunteer to become a prostitute of her own volition, by applying to a notary public for an affidavit. This document has thus amounted to the equivalent of a license, effectively encouraging the practice of prostitution. Simultaneously, it shields the perpetrators of the crime.

According to Bangladesh Mahila Parishad, a study in 1992 found illiterate prostitutes were being forced to sign these affidavits with a left-handed thumbprint, long after they had started practising prostitution. The affidavits legalise the illegitimate deeds of brothel managers, protecting them from the police and judiciary. The unavailability of birth registration data in the countryside allows minors to be registered as adults, facilitating relatively easy access to the legalising affidavits.

The government of Bangladesh adopted the 12 priority concerns enunciated atthe Beijing Conference in 1995, including one regarding sexual exploitation. The government is also trying to implement the UN Child Rights Act. However, law and public opinion do not coincide, rendering the legislation largely ineffective.

\section{Rescue and Rehabilitation}

Bangladesh Mahila Parishad, the NGO which rescued the aforementioned 32 young girls from Kandupatty, a redlight district of Dhaka, acknowledges that a major hurdle for the rehabilitation of those rescued was the desire of girls to go back to the brothels (Maudud 1992), where they receive the good food and clothing their families cannot afford. In attempting to resume a normal life, the girls also face the stigma of social ostracization.

\section{Advocacy}

Prostitution in Bangladesh occurs on a scale comparable in size to other major domestic industries which contribute to the economy. Resourceful and powerful, prostitution managers operate through an elaborate network, and command a variety of resources. In comparison, NGOs and activists have much less access to material resources, lawyers and political clout, with which to fight the menace. However, they are making sincere efforts to advocate the cause of needy women.

In Bangladesh, considerable work has been done with respect to the Convention on the Elimination of All Forms of Discrimination Agains
Women (CEDAW), Article 6 of which explicates that "States Parties shall take all appropriate measures, including legislation, to suppress all forms of traffic in women and exploitation of prostitution of women." The government, aid agencies, and local voluntary organizations are working to promote awareness and generate public debate. A federal ministry responsible for Women's Affairs, as well as specialized NGOs, focus their efforts on gender-related matters, which have begun to attract wider attention in Bangladesh.

\section{Conclusion}

The trafficking of Bangladeshi women within the country and overseas is a systematic abuse of women's rights. Thus, it is a serious human rights issue, calling for the attention of the state, as well as social activists. The issue of licensing needs closer scrutiny, in order to examine how far the law goes in upholding the basic rights of women. II

References

Chowdhury, Elora Halim. 1998. "Organizing Against Sexual Exploitation." Star Magazine, 17 July, 16

Maudud, Baby, ed. 1992. Teen-Agers Are Forced for Flesh Trade. Dhaka, Bangladesh: Mahila

Parishad. LI

\section{Legitimate and Illegitimate Discrimination: New Issues in Migration Edited by Howard Adelman}

\section{Toronto: York Lanes Press, 1995; ISBN 1-55014-238-0; 287 pages, indexed; \$22.95}

Freedom of movement: If the members of a state are forced to flee, the legitimacy of that government is questionable. On the other hand, if members cannot or must leave, again the government is not democratically legitimate.

Immigration control: While limiting access and determining who may or may not become members of a sovereign state remains a legitimate prerogative of the state, the criteria, rules and processes for doing so must be compatible with its character as a democratic state.

Legitimate and Illegitimate Discrimination: New Issues in Migration, edited by Professor Howard Adelman, deals with the question oflegitimacy with cases studies from the Developing World, Europe, Australia, the United States, and Canada.

Contributors:

Rainer Bauböck, Howard Adelman, Gaim Kibreab, A. Essuman-Johnson, GrantM. Farr, LawrenceLam, OscarSchiappa-Pietra, Tomas Hammar, Frédéric Tiberghien (in French), Lois Foster, and Arthur C. Helton.

$$
\text { Available from: }
$$

